\title{
Growth of preterm very low birth weight infants discharged with weight of less than 1500grams
}

\author{
Yaser Abdallah ${ }^{1 *}$, Flavia Namiiro², Jolly Nankunda², Jamiru Mugalu² and Yvonne Vaucher $^{3}$
}

\begin{abstract}
Early discharge of preterm very low birth weight (VLBW) infants is at times inevitable in low resource settings. The implication of such practice on the growth of this high-risk population is not known. We conducted a retrospective chart review to describe the growth of preterm VLBW infants discharged with a weight of less than $1500 \mathrm{~g}$.
\end{abstract}

Objectives: To describe the growth of discharged preterm VLBW infants over the first 12 weeks.

Method: Between June 2013 and January 2014; 164 discharged preterm VLBW infants were followed up for 3 months. Among the survivors (132), we identified 111 infant records for this study. Relevant data was entered in STATA for analysis. Growth percentiles were determined at approximately 4 weeks, 8 weeks, and 12 weeks postdischarge using the intergrowth 21st growth charts. Growth velocities were computed using the 2-point average weight model. Regression analysis was used to identify factors associated with growth failure. Growth failure was defined as occipital frontal circumference (OFC), weight, and length $<10$ th centile by 12 weeks post-discharge. $P$ value of $<0.05$ was considered significant at a $95 \%$ confidence interval.

Results: Among the study infants the median gestational age and weight at birth were 32 weeks (range 28-35 weeks) and $1250 \mathrm{~g}$ (range 850-1500 g) respectively; 60/111(54\%) were Small for Gestational Age (SGA). The median discharge postmenstrual age (PMA) was 34 weeks (range 30-38 weeks) and weight was $1140 \mathrm{~g}$ (range 830-1490 g). The majority $88.2 \%$ had not recovered birth weight at discharge of whom $59.1 \%$ recovered by 2 weeks and $40.9 \%$ recovered between 2 and 4 weeks after discharge. By 12 weeks post-discharge the median PMA and weight were 46 weeks (range $37-51$ weeks), and $3110 \mathrm{~g}$ (range $1750-5000 \mathrm{~g}$ ) respectively, 38.7\% of the infants had growth failure and $36.9 \%$ had OFC $<3$ rd centile. Growth velocity $<15 \mathrm{~g} / \mathrm{kg} / \mathrm{d}$ in the first 4 weeks (OR 3.8, p 0.010) and subsequent 4 weeks (OR 2.5, p 0.049) post-discharge were independently associated with growth failure.

Conclusion: Slow birth weight recovery was observed and growth failure was prevalent by 12 weeks postdischarge with more than a third having severe microcephaly. Poor post-discharge growth velocity was associated with subsequent growth failure.

Recommendations: Growth velocity monitoring among preterm VLBW infants should be emphasized. The implication and interventions of this early growth failure needs to be explored.

\footnotetext{
* Correspondence: yasam786@hotmail.com

${ }^{1}$ Department of Paediatrics and Child Health, Makerere University College of Health Sciences, P.O Box 7072, Kampala, Uganda

Full list of author information is available at the end of the article
}

(C) The Author(s). 2021 Open Access This article is licensed under a Creative Commons Attribution 4.0 International License, which permits use, sharing, adaptation, distribution and reproduction in any medium or format, as long as you give appropriate credit to the original author(s) and the source, provide a link to the Creative Commons licence, and indicate if changes were made. The images or other third party material in this article are included in the article's Creative Commons licence, unless indicated otherwise in a credit line to the material. If material is not included in the article's Creative Commons licence and your intended use is not permitted by statutory regulation or exceeds the permitted use, you will need to obtain permission directly from the copyright holder. To view a copy of this licence, visit http://creativecommons.org/licenses/by/4.0/ The Creative Commons Public Domain Dedication waiver (http://creativecommons.org/publicdomain/zero/1.0/) applies to the data made available in this article, unless otherwise stated in a credit line to the data. 


\section{Background}

It was estimated in 2015 that approximately 20.5million babies were born with low birth weight and the majority 91\% occurred in low and middle-income countries [1]. Low birth weight babies account for $80 \%$ of global neonatal deaths $[2,3]$ of these two-thirds are preterm [1-3]. Surviving preterm and low birth weight babies have been observed to be at risk for morbidities ranging from stunting, ill-health, and adult-onset chronic conditions like cardiovascular diseases among others [4-7]. Low birth weight (LBW) has been associated with the loss of human capital through an increase in high school dropout rate, lowering labor force participation, and early aging [8].

One of the concerns among surviving preterm infants is their growth and its health implications. Various studies have demonstrated that poor growth among preterm very low birth weight infants (VLBW) is associated with poor neurodevelopmental outcomes hence emphasizing the need for promotion and maintaining close to normal early growth among these infants [7, 9, 10]. Nutrition among these infants aims to mimic normal fetal growth to promote development [11].

In the developed countries preterm and VLBW infants are commenced on parenteral nutrition early in life and once on full feeds, their nutritional requirements are adjusted to meet the European Society Paediatric Gastroenterology Hepatology and Nutrition (ESPHAGAN) recommendations [11]. In Low and Middle-income Countries (LMIC) the WHO (world Health Organization) guideline on the feeding of LBW infants is followed, this guideline follows weight gain to decide the next appropriate intervention [12].

At the Mulago National referral hospital, VLBW infants do not routinely receive parenteral nutrition and are discharged home early due to lack of space in the hospital. Parents are educated on how to gavage and breastfeed their infants. Feeding and weight gain are reviewed weekly. Escalation of feeding to fortified breast milk does not happen even among poorly growing LBW infants due to cost and availability.

A previous follow-up of LBW infants at Mulago hospital kangaroo clinic observed the majority of babies not recovering birth weight by 21 days of life [13]. We describe here the growth among a cohort of VLBW infants discharged with a weight of $<1500 \mathrm{~g}$ from the Mulago Special Care Baby Unit (SCBU) over the first 12 weeks post-discharge to guide post-discharge follow-up for such infants.

\section{Methods}

\section{Setting}

This study was conducted at the Mulago Hospital SCBU. The SCBU is a level II neonatal unit that admits approximately 4500 babies annually of whom 20\% are VLBW. Mulago hospital is a National Referral Hospital for Uganda and a teaching hospital for Makerere University.

In terms of nutrition; neonates in the unit are commenced on intravenous fluids containing dextrose as breast milk feeds are introduced slowly. Total fluid requirements are computed daily and are provided as feeds together with supplemental intravenous fluids. Electrolytes are added to intravenous fluids from day 3 of life. Neither intravenous lipids nor amino acids are given routinely. When a neonate is tolerating full feeds (150 $\mathrm{ml} / \mathrm{kg} /$ day) then intravenous fluids are discontinued.

Once preterm and low birth weight babies are stable (i.e., maintaining stable body temperature while in kangaroo care, not needing supplemental oxygen and tolerating feeds), they are discharged home on oral aminophylline, multivitamin drops (Grovit), iron syrup with follow-up once weekly in the Kangaroo clinic located in the SCBU. Most preterm infants are discharged while still tube feeding.

In the Kangaroo clinic anthropometry is done by a trained nurse. Length is measured using an infant length board calibrated to $+/-0.5 \mathrm{~cm}$ accuracy, naked weight by a digital weighing scale calibrated to $+/-10 \mathrm{~g}$ accuracy, and OFC by a none stretchable tape measure. All measurements are performed according to WHO guidelines [14]. Babies are assessed by a paediatrician or a resident in paediatrics. On average the clinic sees 30-40 babies per day.

Babies found with any complication may be readmitted for care while for stable ones; parents are advised on continued care and are given their next appointment. Feed volumes are readjusted (maximum feeding volume is $220 \mathrm{ml} / \mathrm{kg} /$ day), and nasogastric tubes are replaced. Breast milk is never fortified.

Cup feeding and breastfeeding are introduced once the infant shows sucking gestures. If cup feed volume exceeds half daily volume then the nasogastric tube is removed and once sucking on the breast is perceived strong and sustained then full breastfeeding is commenced.

\section{Study population}

The infants included in this cohort were VLBW (birth weight $<1500 \mathrm{~g}$ ), had been discharged home with a weight of $<1500 \mathrm{~g}$, and did not have comorbidities.

\section{Procedure}

Data sheets of all infants enrolled in the previous study on mortality among VLBW infants following hospital discharge were reviewed [15]. Infants who did not survive at 12 weeks post-discharge were excluded from the study. Relevant study variables included: sex, gestational 
Table 1 Comparison of Baseline characteristics and outcomes of study participants

\begin{tabular}{|c|c|c|c|}
\hline Variables Baseline characteristics & $\begin{array}{l}\text { Included participants } \\
\mathrm{N}: 111(\%)\end{array}$ & $\begin{array}{l}\text { Excluded participants } \\
\mathrm{N}: 21(\%)\end{array}$ & p-value \\
\hline \multicolumn{4}{|l|}{ Sex } \\
\hline Male & $53(47.7 \%)$ & $2(9.5 \%)$ & \\
\hline Female & $58(52.2 \%)$ & 19 (90.5\%) & 0.008 \\
\hline \multicolumn{4}{|l|}{ Gestational Age at discharge } \\
\hline$\leq 34$ weeks & $60(54.0 \%)$ & $8(38.1 \%)$ & \\
\hline$>34$ weeks & $51(46.0 \%)$ & 13(61.9\%) & 0.189 \\
\hline \multicolumn{4}{|l|}{ Weight at discharge } \\
\hline$\leq 1200 \mathrm{~g}$ & $73(65.7 \%)$ & $15(71.5 \%)$ & \\
\hline$>1200 \mathrm{~g}$ & $38(34.3 \%)$ & $6(28.5 \%)$ & 0.614 \\
\hline \multicolumn{4}{|l|}{ OFC at birth } \\
\hline$\geq 10$ th centile & $59(53.1 \%)$ & $10(47.6 \%)$ & \\
\hline$<10$ th centile & $52(46.8 \%)$ & $11(52.4 \%)$ & 0.642 \\
\hline \multicolumn{4}{|l|}{ Small for Gestational Age } \\
\hline Yes & $60(54.0 \%)$ & $14(66.6 \%)$ & \\
\hline No & $51(46.0 \%)$ & $7(33.4 \%)$ & 0.536 \\
\hline \multicolumn{4}{|l|}{ HIV exposure } \\
\hline Yes & $18(16.2 \%)$ & $5(23.8 \%)$ & 0.403 \\
\hline No & $93(83.8 \%)$ & $16(76.2 \%)$ & \\
\hline \multicolumn{4}{|l|}{ Twins } \\
\hline Yes & $16(14.4 \%)$ & $1(4.8 \%)$ & 0.251 \\
\hline No & $95(85.6 \%)$ & $20(95.2 \%)$ & \\
\hline \multicolumn{4}{|l|}{ Maternal parity } \\
\hline$<2$ & $33(29.7 \%)$ & $8(38.1 \%)$ & \\
\hline$\geq 2$ & $78(70.3 \%)$ & $13(61.9 \%)$ & 0.450 \\
\hline \multicolumn{4}{|l|}{ Maternal education } \\
\hline None/primary & $43(38,7 \%)$ & $6(28.6 \%)$ & \\
\hline Secondary/tertiary & $68(61.3 \%)$ & $15(71.4 \%)$ & \\
\hline \multicolumn{4}{|l|}{ Maternal income } \\
\hline$<$ 100,000 Ugandan Shillings. & $76(68.5 \%)$ & $6(28.6 \%)$ & \\
\hline$\geq 100,000$ Ugandan Shillings. & 35 (31.5\%) & $15(71.4 \%)$ & \\
\hline
\end{tabular}

\section{Outcome variables}

\section{1st-month KMC hrs}
$<12 \mathrm{~h}$
$83(74.7 \%)$
$\geq 12 \mathrm{~h}$
$28(25.3 \%)$
Unknown
$0(0.0 \%)$

$7(33.3 \%)$

$6(28.6 \%)$

$8(38.0 \%)$

Birth weight recovery 2 weeks post-discharge

Yes
No
Unknown

KMC support

Yes

$71(63.9 \%)$

$8(38.1 \%)$

$40(36.1 \%)$

$8(38.1 \%)$

0 (0.0\%)

$5(23.8 \%)$

No

$24(21.6 \%)$
$87(78.4 \%)$

5 (23.8\%)

$16(76.2 \%)$

Weight 12 weeks after discharge 
Table 1 Comparison of Baseline characteristics and outcomes of study participants (Continued)

\begin{tabular}{cll}
\hline Variables Baseline characteristics & $\begin{array}{l}\text { Included participants } \\
\mathbf{N}: \mathbf{1 1 1}(\%)\end{array}$ & $\begin{array}{l}\text { Excluded participants } \\
\mathbf{N}: \mathbf{2 1}(\%)\end{array}$ \\
\hline$\geq 10$ th centile & $28(25.1 \%)$ & $5(23.8 \%)$ \\
$<10$ th centile & $83(74.9 \%)$ & $8(38.1 \%)$ \\
Unknown & $0(0.0 \%)$ & $8(38.1 \%)$ \\
OFC $\mathbf{1 2}$ weeks after discharge & & \\
$\geq 1$ 10th centile & $68(61.3 \%)$ & $6(28.6 \%)$ \\
$<1$ 10th centile & $43(38.7 \%)$ a & $4(19.0 \%)$ \\
Unknown & $0(0.0 \%)$ & $11(52.4 \%)$ \\
\hline
\end{tabular}

a: 41 of the 43 had OFC <3rd centile

age, hospitalizations, weight, length, and head circumference at birth, discharge, 4 weeks, 8 weeks, and 12 weeks post-discharge. Other variables were maternal age, parity, mode of feeding, kangaroo hours, Human Immunodeficiency Virus (HIV) status. Only complete data sheets were included in the analysis. Growth failure was defined as having weight, OFC, and length below 10th centile at 12 weeks post-discharge using the 21st intergrowth chart [16].

\section{Data management and analysis}

Data were entered into the computer using the Microsoft Excel program and subsequently exported into the STATA software package for analysis. The intergrowth online tool was used to compute weight, OFC, and length centile at the different postmenstrual ages.

Growth velocity was computed as

$$
\mathrm{GV}=\left[\frac{(\mathrm{Wte}(\mathrm{g})-\mathrm{Wts}(\mathrm{g})}{\mathrm{P}}\right] \div \frac{\mathrm{Wte}(\mathrm{kg})+\mathrm{Wts}(\mathrm{kg})}{2}
$$

$\mathrm{GV}=$ Growth Velocity.

Wte $=$ weight at end of assessment.

Wts $=$ weight at start of assessment.

$\mathrm{P}=$ Period of assessment in days (age at Wte less age at Wts).

The Pearson Chi-square test was performed to compare baseline characteristics between included and excluded study participants.
Using baseline variables logistic regression was run to identify factors independently associated with growth failure. $P$ values of $<0.05$ were considered significant and the confidence interval of $95 \%$ was used. The results were summarized in tables.

\section{Results}

Of the 132 preterm VLBW $(<1500 \mathrm{~g})$, infants born between June 2013 and January 2014 who were known to be alive at 12 weeks post-discharge, we identified 111 infants (53 males and 58 females) with complete records. The median gestational age and weight at birth were 32.5 weeks (range 28-35 weeks) and $1250 \mathrm{~g}$ (range (8501500 g) respectively. Sixty were SGA of whom 45/111 $(40.5 \%)$ and $15 / 111(13.5 \%)$ were symmetrically and asymmetrically SGA respectively at birth. Baseline cohort characteristics are shown in Table 1.

Although most of infants excluded from analysis were female 19/21 (p 0.008), the baseline characteristics among included and excluded infants were not statistically significant Table 1 .

The average duration of hospital stay was 12 days (range 4-41 days). The median discharge PMA and weight were 34 weeks (range 30-38 weeks) and $1140 \mathrm{~g}$ (range 830-1490 g). Birth weight was recovered in only 13(11.7\%) infants at discharge, in whom the average time to birth weight recovery was at 12.6 days (range7-21 day).

Table 2 Post-discharge gestational ages, weight, and KMC hours

\begin{tabular}{|c|c|c|c|c|c|c|c|}
\hline \multirow{2}{*}{$\begin{array}{l}\text { Weeks } \\
\text { Post- } \\
\text { discharge }\end{array}$} & \multirow{2}{*}{$\begin{array}{l}\text { Median } \\
\text { Post- } \\
\text { menstrual } \\
\text { age } \\
\text { (range) }\end{array}$} & \multirow{2}{*}{$\begin{array}{l}\text { Number of } \\
\text { infants with } \\
\text { Gestational } \\
\text { age }<35 \\
\text { weeks }\end{array}$} & \multirow{2}{*}{$\begin{array}{l}\text { Median } \\
\text { weight } \\
\text { (range) } \\
\text { grams }\end{array}$} & \multirow[b]{2}{*}{$\begin{array}{l}\text { Number } \\
\text { of } \\
\text { infants } \\
\text { with } \\
\text { weight < } \\
2500 \mathrm{~g}\end{array}$} & \multicolumn{3}{|c|}{ Number of infants Receiving KMC } \\
\hline & & & & & $>20 \mathrm{~h}$ & $12-20 \mathrm{~h}$ & $<12 \mathrm{~h}$ \\
\hline 4 weeks & $39(34-41)$ & 9 & $1630(1030-2800)$ & 108 & 0 & 28 & 83 \\
\hline 8 weeks & $42(36-46)$ & 1 & $2477(1280-4220)$ & 62 & 0 & 9 & 102 \\
\hline 12 weeks & $45(37-51)$ & 0 & $3293(1750-5000)$ & 10 & 0 & 2 & 107 \\
\hline
\end{tabular}




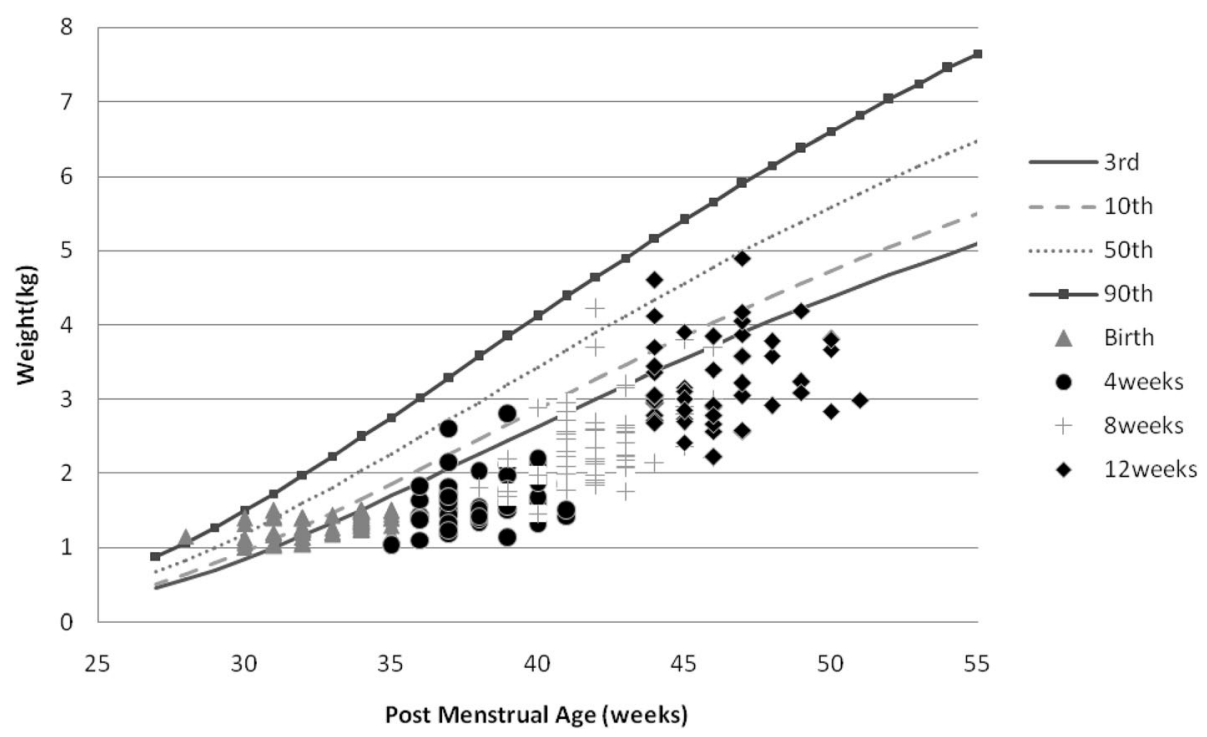

Fig. 1 Post-discharge weight changes of Preterm/VLBW boys

The majority of the infants at discharge were still tube feeding 100/111. By 12 weeks after discharge 107/111 infants were exclusively breastfeeding directly from the breast and 4 were taking formula feeds.

Of the infants who had not recovered birth weight at discharge 98 (88.2\%); 70 (71.4\%) weighed $\leq 1200$ g at discharge. Among these infants 58(59.1\%) recovered birth weight by 2 weeks after discharge. Among those who recovered birth weight between 2 and 4 weeks after discharge $40(40.8 \%)$ the majority $34 / 40$ were those discharged with weight of $\leq 1200 \mathrm{~g}$.

In the first 4 weeks post-discharge, 28mothers were practicing Kangaroo Mother Care (KMC) for 12-20 h per day; by 8 weeks post-discharge; 9 mothers were doing so (Table 2).

Between discharge and 4 weeks post-discharge 8 infants were hospitalized for possible sepsis, 3 of them subsequently had growth failure; between 4 and 8 weeks

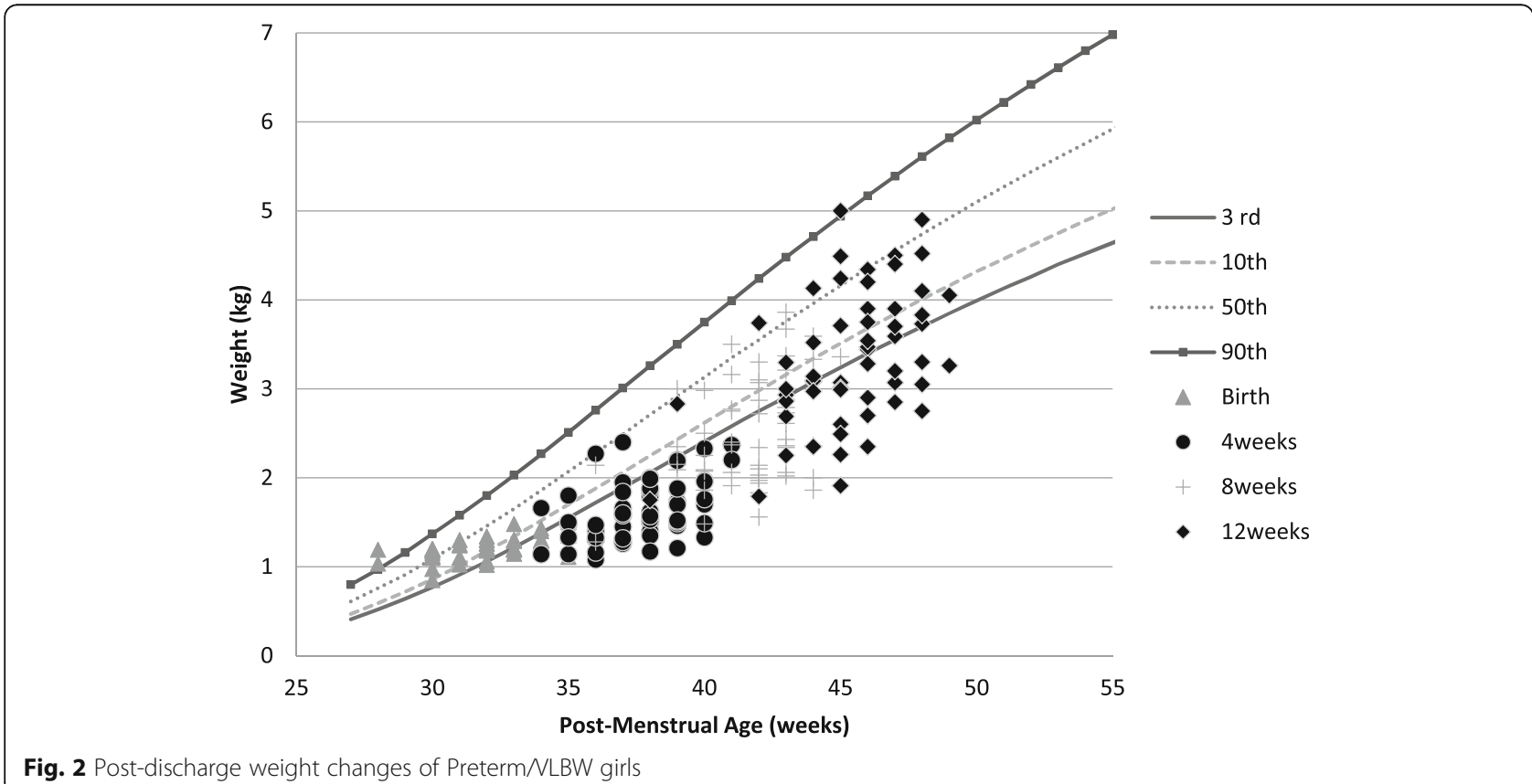

Fig. 2 Post-discharge weight changes of Preterm/NLBW girls 


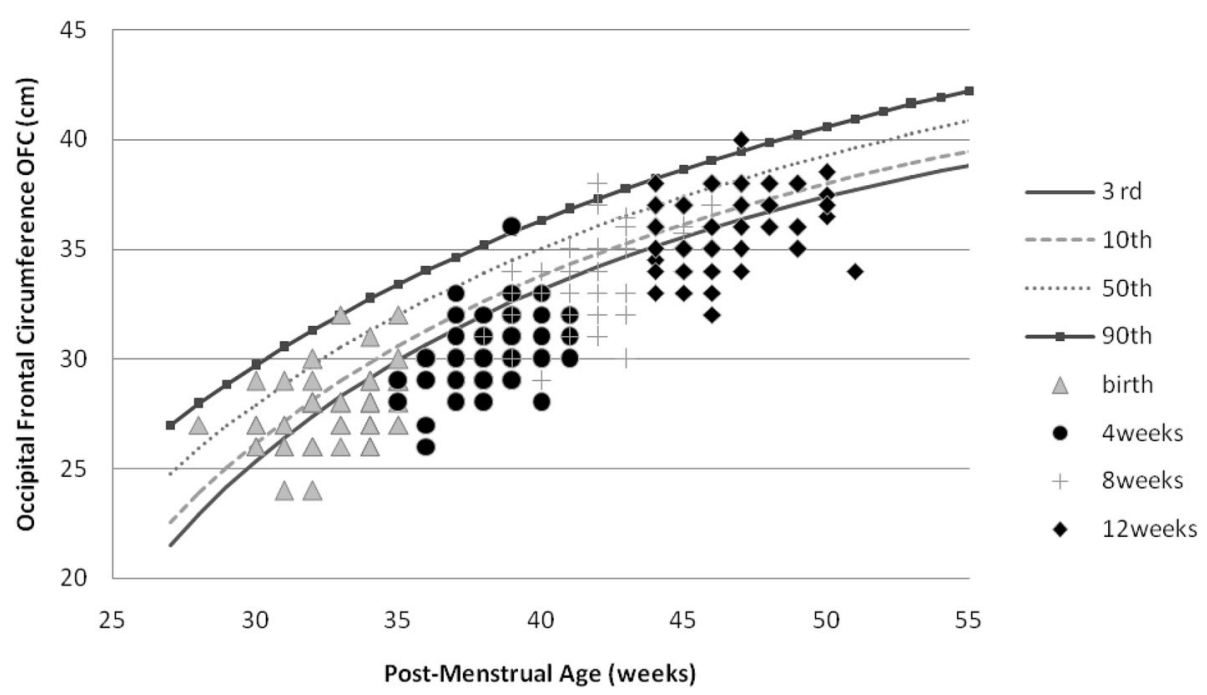

Fig. 3 Post-discharge head growth of Preterm/NLBW boys

post-discharge 1 infant was hospitalized for anemia and between 8 and 12 weeks 2 infants were hospitalized for pneumonia.

By12 weeks post-discharge the median PMA and weight were 46 weeks (range 37-51 weeks) and $3110 \mathrm{~g}$ (range 1750-5000 g) respectively. The majority of the infants had weight $73.8 \%$ and length $72.6 \%$ below 10th centile. Growth failure was evident in 43/111 (38.7\%) infants. Forty-one $(36.9 \%)$ infants had $\mathrm{OFC}<3$ rd centile (Table 1).

Girls had an overall better weight, length, and OFC recovery than boys (Figs. 1, 2, 3, 4, 5 and 6 and Table 3).

\section{Discussion}

From this analysis, $38.7 \%$ of the preterm VLBW infants had growth failure with weight, length and head circumference below the 10th percentile for PMA by 12 weeks post-discharge. Growth failure was more frequent among SGA infants 28/60 (46.6\%) compared to $15 /$ $51(29.4 \%)$ of non-SGA infants although this difference was statistically not significant (p 0.06) (Table 4).

Only $13(11.7 \%)$ of the study infants had recovered birth weight at the time of hospital discharge. Of these 8 were appropriately grown for gestational age and 5 were SGA at birth. This very slow birth weight

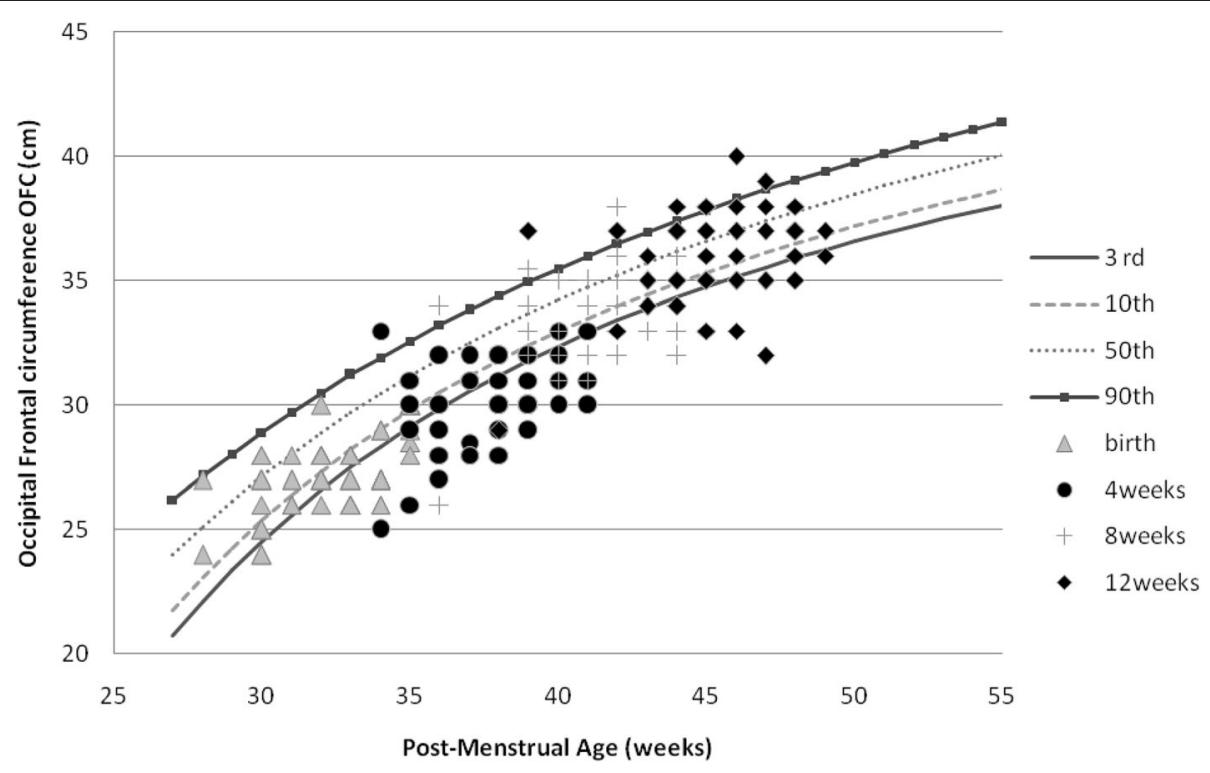

Fig. 4 Post-discharge head growth of Preterm/VLBW girls 


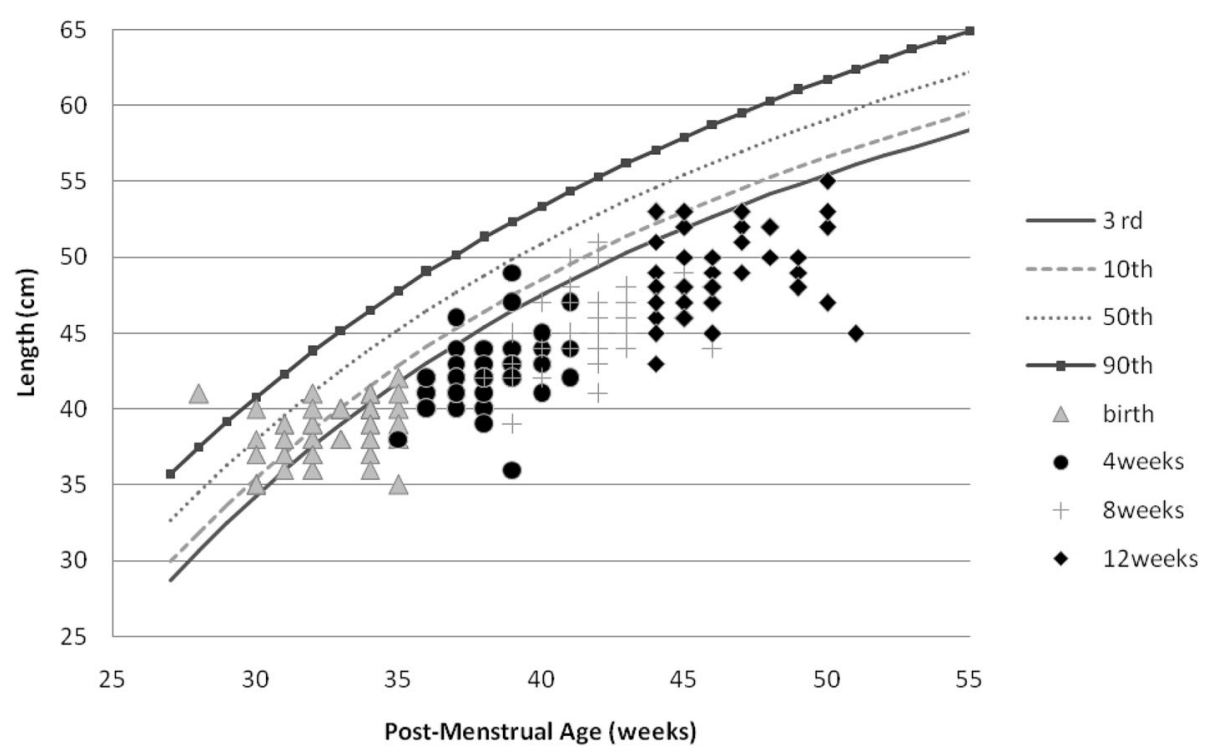

Fig. 5 Post-discharge length changes of Preterm/NLBW boys

recovery is comparable to findings from a study conducted in the same facility among none SGA low birth weight infants [13], but slower than findings from other studies [17-19]. This observation can be explained by the difference in practice between our facility and others. In our facility, VLBW infants do not routinely receive total parenteral nutrition as enteral feeds are introduced.

Of the 98/111(88.2\%) discharged home before birth weight recovery; $58(59.1 \%)$ recovered birth weight by 2 weeks after discharge and 40(40.9\%) recovered 2-4 weeks after discharge. Whereas discharge weight of $\leq 1200 \mathrm{~g}$ did not seem to be significantly associated with growth failure (OR 1.34 p 0.48) (Table 4), the majority of infants $34 / 40(85 \%)$ who had not recovered birth weight by 2 weeks post-discharge were those discharged with a weight of $\leq 1200 \mathrm{~g}$. Infants discharged with weight $\leq 1200 \mathrm{~g}$ are likely to be more immature and more susceptible to environmental stressors such as hypothermia accounting for slower growth among this weight category.

By 4 weeks post-discharge 28/111 (25.2\%) infants were reportedly receiving KMC for $12-20 \mathrm{~h} /$ day (Table 2). Despite kangaroo mother care being associated

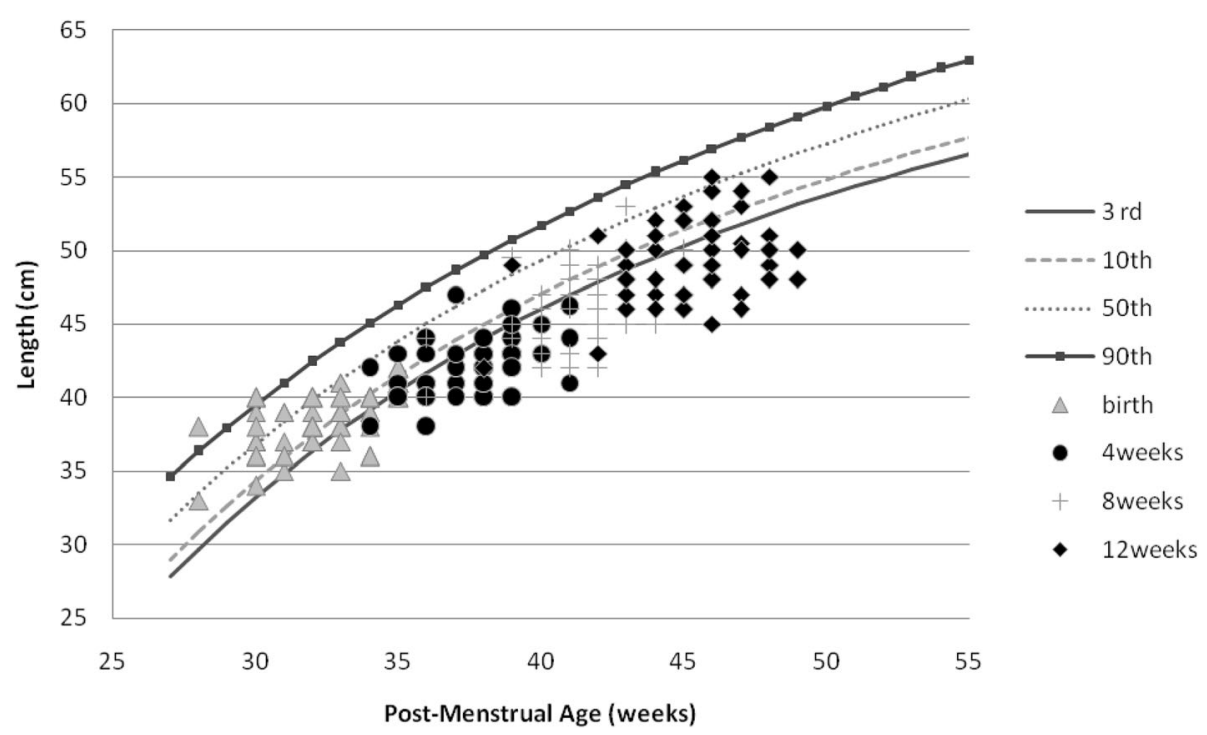

Fig. 6 Post-discharge length changes of Preterm/VLBW girls 
Table 3 Comparison of growth between girls and boys

\begin{tabular}{|c|c|c|c|}
\hline Anthropometry & $\begin{array}{l}\text { Boys } \\
\text { N: } 53(\%)\end{array}$ & $\begin{array}{l}\text { Girls } \\
\text { N: } 58 \text { (\%) }\end{array}$ & $\begin{array}{l}\text { Total } \\
\text { N: } 111 \text { (\%) }\end{array}$ \\
\hline \multicolumn{4}{|l|}{ Birth weight } \\
\hline$\geq 10$ th centile & $23(43.4 \%)$ & $28(48.2 \%)$ & $51(46.0 \%)$ \\
\hline$<10$ th centile & $30(56.6 \%)$ & $30(51.8 \%)$ & $60(54.0 \%)$ \\
\hline \multicolumn{4}{|c|}{ Weight 12 weeks post discharge } \\
\hline$\geq 10$ th centile & $9(17.0 \%)$ & $19(32.8 \%)$ & $28(25.2 \%)$ \\
\hline$<10$ th centile & $44(83.0 \%)$ & $39(67.2 \%)$ & $83(74.8 \%)^{b}$ \\
\hline \multicolumn{4}{|l|}{ OFC birth } \\
\hline$\geq 10$ th centile & $21(39.6 \%)$ & $38(65.5 \%)$ & $59(53.1 \%)$ \\
\hline$<10$ th centile & $32(60.4 \%)$ & $20(34.5 \%)$ & $52(46.9 \%)$ \\
\hline \multicolumn{4}{|c|}{ OFC 12 weeks post discharge } \\
\hline$\geq 10$ th centile & $28(52.8 \%)$ & $40(69.0 \%)$ & $68(61.3 \%)$ \\
\hline$<10$ th centile & $25(47.2 \%)$ & 18(31.0\%) & $43(38.7 \%)^{c}$ \\
\hline \multicolumn{4}{|l|}{ Length birth } \\
\hline$\geq 10$ th centile & $24(45.3 \%)$ & $39(67.2 \%)$ & $63(56.7 \%)$ \\
\hline$<10$ th centile & $29(54.7 \%)$ & 19(32.8\%) & $48(43.3 \%)$ \\
\hline \multicolumn{4}{|c|}{ Length 12 weeks post discharge } \\
\hline$\geq 10$ th centile & $7(13.2 \%)$ & $23(39.6 \%)$ & $30(27.0 \%)$ \\
\hline$<10$ th centile & $46(86.8 \%)$ & $35(60.4 \%)$ & $81(73.0 \%)$ \\
\hline \multicolumn{4}{|c|}{ Symmetric SGA at birth ${ }^{a}$} \\
\hline Yes & $25(47.1 \%)$ & $20(34.5 \%)$ & $45(40.5 \%)$ \\
\hline No & $28(52.8 \%)$ & $38(65.5 \%)$ & $66(59.5 \%)$ \\
\hline
\end{tabular}

: Symmetric SGA $=$ Weight, FC and Length $<10$ th centile for gestational age

${ }^{b}$ : Of these $83 ; 48$ had weight $<10$ thcentile at birth

$c$ : Of these $43 ; 26$ had OFC $<10$ th centile at birth

with improved growth beyond 40 weeks postmenstrual age [20];our study participants were not receiving continuous KMC as recommended [21, 22] this exposed them to increased caloric needs for maintaining body temperature possibly at the expense of growth. It is important that continuous $\mathrm{KMC}$ is emphasized and supported in the community in low resource settings.

Growth velocity $<15 \mathrm{~g} / \mathrm{kg} / \mathrm{d}$ in the first 4 weeks (OR $3.8, \mathrm{p}$ 0.010) and subsequent 4 weeks (OR 2.5, p $0.049)$ post-discharge were independently associated with growth failure (Table 4). Early post-natal growth has been positively associated with neurodevelopment outcomes among preterm infants [7, 10]. ESPHGAN recommends a growth velocity of $17-20 \mathrm{~g} / \mathrm{kg} / \mathrm{d}$ to prevent preterm infants from dropping off their centile lines [23] and a growth velocity of $16.2+/-2.4 \mathrm{~g} / \mathrm{kg} / \mathrm{d}$ has been shown to be achievable for VLBW infants on full feeds of $200 \mathrm{mls} / \mathrm{kg} / \mathrm{d}$ once the birth weight has been recovered [18]. Despite being on full feeds; the majority $65.7 \%$ of our study infants had growth velocity $<15 \mathrm{~g} / \mathrm{kg} / \mathrm{d}$ (Table 4 ) between discharge and 4 weeks post-discharge. This finding can be explained by the accrued negative protein balance our study participants encounter since parenteral amino acids were not provided as enteral feeds were introduced during their hospital stay.

The majority of our study infants 59/111 (53.1\%) had normal OFC at birth of these $17(28.8 \%)$ had OFC below the 10th centile by 12 weeks post-discharge while those who had OFC below 10th centile at birth 52/111(46.9\%) by 12 weeks post-discharge $26(50 \%)$ still had OFC < 10th centile (Table 3). From Figs. 3 and 4 it is evident that OFC dropped off the centile lines but by 12 weeks post-discharge there seems to be a recovery of OFC compared to weight and length Figs. 1, 2, 5 and 6. Poor early post-natal head growth has been associated with adverse neurodevelopmental outcomes [9], this may imply a higher neurodevelopmental impairment for our study infants.

We noted both boys and girls drifted off their centile lines by 4 weeks post discharge (Figs. 1 and 2), by 8 weeks post discharge girls started recovering back to their appropriate centile line for PMA and by 12 weeks post discharge $32.8 \%$ of girls were above the 10 th centile compared to $17 \%$ of boys (Table 3 ), similar trend is observed with length (Figs. 5 and 6) and by 12 weeks post discharge $39.6 \%$ of the girls had length above the $10^{\text {th }}$ centile compared to $13.2 \%$ of boys (Table 3 ). These observations are contrary to what is expected as per intergrowth 21st charts [16] since boys are expected to attain higher anthropometric measurements compared to girls. This observation may be explained by the fact that more boys (47.1\%) were symmetrically growth restricted at birth as compared to the girls $(34.5 \%)$ (Table 3 ).

Slow birth weight recovery was observed with growth failure prevalent by 12 weeks post-discharge in the majority of VLBW infants in this study with more than a third having severe microcephaly. Enhanced early nutrition has been shown to ameliorate poor postnatal head growth a practice that LMIC should consider in the care of preterm VLBW infants to avert poor early head growth and improve long term neurodevelopmental outcome.

\section{Conclusion}

Growth velocity monitoring among preterm VLBW infants should be emphasized. The implication and interventions of this early growth failure needs to be explored.

\section{Limitations}

We could not ascertain accurately the volume of feeds the study infants received since some of them were breastfeeding as well as receiving top-up feeds by tube/ 
Table 4 Factors associated with growth failure

\begin{tabular}{|c|c|c|c|c|c|c|}
\hline Variables & $\begin{array}{l}\text { No Growth failure } \\
\mathrm{N}: 68(\%)\end{array}$ & $\begin{array}{l}\text { Growth failure } \\
\mathrm{N}: 43(\%)\end{array}$ & COR & $\mathrm{p}$-value & AOR & p-value \\
\hline \multicolumn{7}{|l|}{ Sex } \\
\hline Male & $28(41.2 \%)$ & $25(58.1 \%)$ & $1.98(0.91-4.30)$ & 0.081 & $1.23(0.50-3.00)$ & 0.644 \\
\hline Female & $40(58.8 \%)$ & 18(41.9\%) & & & & \\
\hline \multicolumn{7}{|c|}{ Gestational Age at discharge } \\
\hline$\leq 34$ weeks & $39(57.3 \%)$ & $21(48.8 \%)$ & $0.71(0.33-1.53)$ & 0.38 & & \\
\hline$>34$ weeks & $29(42.7 \%)$ & $22(51.2 \%)$ & & & & \\
\hline \multicolumn{7}{|l|}{ Weight at discharge } \\
\hline$\leq 1200 \mathrm{~g}$ & $43(63.2 \%)$ & $30(69.8 \%)$ & $1.34(0.96-4.62)$ & 0.48 & & \\
\hline$>1200 \mathrm{~g}$ & $25(36.8 \%)$ & $13(30.2 \%)$ & & & & \\
\hline \multicolumn{7}{|l|}{ Small for Gestational Age } \\
\hline Yes & $32(47.0 \%)$ & $28(65.1 \%)$ & $2.10(0.95-4.61)$ & 0.064 & $2.30(0.94-5.62)$ & 0.06 \\
\hline No & $36(53.0 \%)$ & $15(34.9 \%)$ & & & & \\
\hline \multicolumn{7}{|l|}{ HIV exposure } \\
\hline Yes & $10(14.7 \%)$ & $8(18.6 \%)$ & $1.33(0.47-3.67)$ & 0.588 & & \\
\hline No & $58(85.3 \%)$ & $35(81.4 \%)$ & & & & \\
\hline \multicolumn{7}{|l|}{ Twins } \\
\hline Yes & 10(14.7\%) & $6(14.0 \%)$ & $0.94(0.31-2.80)$ & 0.912 & & \\
\hline No & $58(85.3 \%)$ & $37(86.0 \%)$ & & & & \\
\hline \multicolumn{7}{|l|}{ 1st-month KMC hrs } \\
\hline$<12 \mathrm{~h}$ & $51(75.0 \%)$ & $32(74.4 \%)$ & $0.97(0.40-2.33)$ & 0.94 & & \\
\hline$\geq 12 \mathrm{~h}$ & $17(25.0 \%)$ & $11(25.6 \%)$ & & & & \\
\hline \multicolumn{7}{|c|}{ Birth weight recovery 2 weeks post-discharge } \\
\hline Yes & $50(73.5 \%)$ & $21(48.8 \%)$ & $2,91(1.30-6.50)$ & 0.009 & $2.26(0.92-5.54)$ & 0.072 \\
\hline No & $18(26.5 \%)$ & $22(51.2 \%)$ & & & & \\
\hline \multicolumn{7}{|c|}{ Growth velocity 1 (discharge to 4 weeks later) } \\
\hline$<15 \mathrm{~g} / \mathrm{kg} / \mathrm{day}$ & $37(54.4 \%)$ & $36(83.7 \%)$ & $4.31(1.68-11.0)$ & 0.002 & $3.89(1.38-10.9)$ & 0.010 \\
\hline$\geq 15 \mathrm{~g} / \mathrm{kg} / \mathrm{day}$ & $31(45.6 \%)$ & $7(16.3 \%)$ & & & & \\
\hline \multicolumn{7}{|c|}{ Growth velocity 2 (4to 8 weeks after discharge) } \\
\hline$<15 \mathrm{~g} / \mathrm{kg} / \mathrm{day}$ & $35(51.5 \%)$ & $32(74.4 \%)$ & $2.74(1.19-6.32)$ & 0.018 & $2.50(1.01-6.27)$ & 0.049 \\
\hline$\geq 15 \mathrm{~g} / \mathrm{kg} / \mathrm{day}$ & $33(48.5 \%)$ & $11(25.6 \%)$ & & & & \\
\hline \multicolumn{7}{|c|}{$\begin{array}{l}\text { Growth velocity } 3 \\
\text { (8 to12weeks after discharge) }\end{array}$} \\
\hline$<15 \mathrm{~g} / \mathrm{kg} / \mathrm{day}$ & $61(89.7 \%)$ & $37(86.0 \%)$ & $0.71(0.22-2.27)$ & 0.561 & & \\
\hline$\geq 15 \mathrm{~g} / \mathrm{kg} / \mathrm{day}$ & $7(10.3 \%)$ & $6(14.0 \%)$ & & & & \\
\hline \multicolumn{7}{|l|}{ Maternal parity } \\
\hline$<2$ & $21(31.0 \%)$ & $12(27.9 \%)$ & $0.866(0.37-2.01)$ & 0.738 & & \\
\hline$\geq 2$ & $47(69.0 \%)$ & $31(72.1 \%)$ & & & & \\
\hline \multicolumn{7}{|l|}{ Maternal education } \\
\hline None/primary & $29(42.6 \%)$ & $14(32.5 \%)$ & $0.64(0.29-1.44)$ & 0.289 & & \\
\hline Secondary/tertiary & $39(57.4 \%)$ & $29(67.5 \%)$ & & & & \\
\hline \multicolumn{7}{|l|}{ Maternal income } \\
\hline$<100,000$ Ugandan Shs. & $50(73.5 \%)$ & $26(60.4 \%)$ & $0.55(0.24-1.24)$ & 0.151 & $0.40(0.155-1.05)$ & 0.063 \\
\hline$\geq 100,000$ Ugandan Shs. & $18(26.5 \%)$ & $17(39.6 \%)$ & & & & \\
\hline \multicolumn{7}{|l|}{ KMC support } \\
\hline Yes & $15(22.0 \%)$ & $9(20.9 \%)$ & $1.07(0.42-2.72)$ & 0.88 & & \\
\hline No & 53(78.0\%) & $34(79.1 \%)$ & & & & \\
\hline
\end{tabular}


cup. The duration $\mathrm{KMC}$ was as reported by the mothers and subject to recall bias.

Considering a large proportion of our study infants were SGA with $40.5 \%$ being symmetrically growth restricted and these infants showing higher tendency to growth failure, other intrinsic factor beyond this study for growth failure among this population cannot be excluded.

We did not analyze for factors associated with growth failure among SGA because of a small sample size and possibility of intrinsic factors for which our study was not design to identify.

\section{What is known}

Preterm very low birth weight infants are at risk for growth failure.

\section{What this study adds}

Early discharge with weight of less than $1500 \mathrm{~g}$ may results in slower birth weight recovery and high growth failure.

\section{Abbreviations \\ ESPGHAN: European Society for Pediatric Gastroenterology Hepatology and Nutrition; HIV: Human Immunodeficiency Virus; KMC: Kangaroo Mother Care; LBW: Low Birth Weight; MLIC: Middle and Low Income Countries; OFC: Occipital Frontal Circumference; PMA: Post-Menstrual Age; SCBU: Special Care Baby Unit; SGA: Small for Gestational Age; VLBW: Very Low Birth Weight; WHO: World Health Organization}

\section{Acknowledgements}

We would like to thank the parents of the study infants, the nursing staff of the Mulago hospital SCBU for the role they had in this piece of work.

\section{Authors' contributions}

A Literature search was done by Y. A and N. F, data was entered by Y. A N. J, and M. J reviewed the methodology and Y. V reviewed the write-up. The authors read and approved the final manuscript.

\section{Funding}

This study did not receive any external funding.

\section{Availability of data and materials}

The data from this study is available with the corresponding author and can be accessed on request.

\section{Declarations}

\section{Ethics approval}

Ethical clearance to conduct this study was obtained from the Uganda National Counsel of Science and Technology which is the national research and ethics approving body. Written informed consent was obtained from all the parents of the study infants. All study procedures were performed according to approved protocol and the units' daily procedures.

\section{Consent for publication}

This was obtained from the parents of study infants and from the Uganda National Counsel of Science and Technology.

\section{Competing interests}

None of the authors have any competing interest to declare.

\section{Author details}

'Department of Paediatrics and Child Health, Makerere University College of Health Sciences, P.O Box 7072, Kampala, Uganda. ${ }^{2}$ Department of Paediatrics and Child Health, Mulago National Referral hospital, Kampala, Uganda. ${ }^{3}$ Department of Pediatrics, Division of Neonatal/Perinatal Medicine, School of Medicine, University of California at San Diego, San Diego, USA.

Received: 18 October 2020 Accepted: 12 March 2021

Published online: 25 March 2021

\section{References}

1. Blencowe H, Krasevec J, de Onis M, et al. National, regional, and worldwide estimates of low birthweight in 2015, with trends from 2000: a systematic analysis. Lancet Glob Health. 2019:(7):e849-60.

2. Katz J, Lee AC, Kozuki N, Lawn JE, Cousens S, Blencowe H, Ezzati M, Bhutta ZA, Marchant T, Willey BA, Adair L, Barros F, Baqui AH, Christian P, Fawzi W, Gonzalez R, Humphrey J, Huybregts L, Kolsteren P, Mongkolchati A, Mullany LC, Ndyomugyenyi R, Nien JK, Osrin D, Roberfroid D, Sania A, Schmiegelow C, Silveira MF, Tielsch J, Vaidya A, Velaphi SC, Victora CG, Watson-Jones D, Black RE, CHERG Small-for-Gestational-Age-Preterm Birth Working Group. Mortality risk in preterm and small-for-gestational-age infants in low-income and middle-income countries: a pooled country analysis. Lancet. 2013; 382(9890):417-25. https://doi.org/10.1016/S0140-6736(13)60993-9.

3. Lawn JE, Blencowe H, Oza S, You D, Lee AC, Waiswa P, et al. Every Newborn: progress, priorities, and potential beyond survival. Lancet. 2014; 384(9938):189-205. https://doi.org/10.1016/50140-6736(14)60496-7.

4. Gluckman PD, Hanson MA, Beedle AS. Early life events and their consequences for later disease: a life history and evolutionary perspective. Am J Human Biol. 2007;19(1):1-19. https://doi.org/10.1002/ajhb.20590.

5. Christian P, Lee SE, Donahue Angel M, Adair LS, Arifeen SE, Ashorn P, Barros FC, Fall CHD, Fawzi WW, Hao W, Hu G, Humphrey JH, Huybregts L, Joglekar CV, Kariuki SK, Kolsteren P, Krishnaveni GV, Liu E, Martorell R, Osrin D, Persson LA, Ramakrishnan U, Richter L, Roberfroid D, Sania A, ter Kuile FO, Tielsch J, Victora CG, Yajnik CS, Yan H, Zeng L, Black RE. Risk of childhood undernutrition related to small-for-gestational age and preterm birth in lowand middle-income countries. Int J Epidemiol. 2013;42(5):1340-55. https:// doi.org/10.1093/ije/dyt109.

6. Fall CH. Fetal malnutrition and long-term outcomes. Nestle Nutr Inst Workshop Ser. 2013;74:11-25. https://doi.org/10.1159/000348384.

7. Guellec I, Lapillonne A, Marret S, Picaud JC, Mitanchez D, Charkaluk ML, et al. Effect of Intra- and Extrauterine Growth on Long-Term Neurologic Outcomes of Very Preterm Infants. J Pediatr. 2016;175:93-9 e1.

8. Johnson RC, Robert F. Schoeni. The Influence of Early-Life Events on Human Capital, Haelth Status and Labor Market Outcomes Over the Life Course. B E J Econom Anal Policy. 2011;6(11(3)):2521.

9. Neubauer V, Griesmaier E, Pehbock-Walser N, Pupp-Peglow U, KiechlKohlendorfer U. Poor postnatal head growth in very preterm infants is associated with impaired neurodevelopment outcome. Acta Paediatr. 2013; 102(9):883-8. https://doi.org/10.1111/apa.12319.

10. Taine M, Charles MA, Beltrand J, Roze JC, Leger J, Botton J, et al. Early postnatal growth and neurodevelopment in children born moderately preterm or small for gestational age at term: a systematic review. Paediatr Perinat Epidemiol. 2018;32(3):268-80. https://doi.org/10.1111/ppe.12468.

11. Agostoni C, Buonocore G, Carnielli VP, De Curtis M, Darmaun D, Decsi T, et al. Enteral nutrient supply for preterm infants: commentary from the European Society of Paediatric Gastroenterology, Hepatology and nutrition committee on nutrition. J Pediatr Gastroenterol Nutr. 2010;50(1):85-91. https://doi.org/10.1097/MPG.0b013e3181adaee0.

12. World Health Organization editor. Optimal feeding of low birth weight infants in low and middle income countries. Switzerland: World Health Organization; 2011.

13. Namiiro FB, Mugalu J, McAdams RM, Ndeezi G. Poor birth weight recovery among low birth weight/preterm infants following hospital discharge in Kampala, Uganda. BMC Pregnancy Childbirth. 2012;12:1 2393-12-1.

14. de Onis M, Garza C, Victora CG, Bhan MK, Norum K. The WHO Multicentre Growth Reference Study (MGRS): rationale, planning, and implementation. Food Nutr Bull. 2004;25(s1-90):31-2.

15. Yaser A, Namiiro F, Nankunda J, Mugalu J, Vaucher Y. Mortality among very low birth weight infants after hospital discharge in a low resource setting. BMN Pediatrics. 2018;18(239)

16. Villar J, Cheikh Ismail L, Victora CG, Ohuma EO, Bertino E, Altman DG, et al. International standards for newborn weight, length, and head circumference by gestational age and sex: the Newborn cross-sectional 
study of the INTERGROWTH-21st project. Lancet. 2014;384(9946):857-68. https://doi.org/10.1016/50140-6736(14)60932-6.

17. Mudahemuka JC, Ballot DE. Birth weight recovery among very low birth weight infants surviving to discharge from Charlotte Maxeke Johannesburg academic hospital. S Afr J CH. 2014;8(4):149-53. https://doi.org/10.7196/sa jch.709.

18. Georgie M, Vijay G, Sridhar S, Grace R. Postnatal weight gain patterns in preterm very-low-birth-weight infants born in a tertiary Care Center in South India. J Trop Pediatr. 2018;64:126-31.

19. Henriksen C, Westerberg AC, Ronnestad A, Nakstad B, Veierod MB, Drevon $C A$, et al. Growth and nutrient intake among very-low-birth-weight infants fed fortified human milk during hospitalisation. Br J Nutr. 2009;102(8):117986. https://doi.org/10.1017/S0007114509371755.

20. Conde-Agudelo A, Diaz-Rossello JL. Kangaroo mother care to reduce morbidity and mortality in low birthweight infants. Cochrane Database Syst Rev. 2016;(8):CD002771 doi(8):CD002771

21. Nyqvist KH, Anderson GC, Bergman N, Cattaneo A, Charpak N, Davanzo R, Ewald U, Ibe O, Ludington-Hoe S, Mendoza S, Pallás-Allonso C, Ruiz Peláez JG, Sizun J, Widström AM. Towards universal kangaroo mother care: recommendations and report from the first European conference and seventh international workshop on kangaroo mother care. Acta Paediatr. 2010;99(6):820-6. https://doi.org/10.1111/j.1651-2227.2010.01787.x.

22. World Health Organization. WHO recommendations on interventions to improve preterm birth outcomes. 2015; ISBN 9789241508988

23. Joosten K, Embleton N, Yan W, Senterre T. ESPGHAN/ESPEN/ESPR/CSPEN guidelines on pediatric parenteral nutrition: Energy. Clin Nutr. 2018;37: 2309-14.

\section{Publisher's Note}

Springer Nature remains neutral with regard to jurisdictional claims in published maps and institutional affiliations.

Ready to submit your research? Choose BMC and benefit from:

- fast, convenient online submission

- thorough peer review by experienced researchers in your field

- rapid publication on acceptance

- support for research data, including large and complex data types

- gold Open Access which fosters wider collaboration and increased citations

- maximum visibility for your research: over $100 \mathrm{M}$ website views per year

At $\mathrm{BMC}$, research is always in progress.

Learn more biomedcentral.com/submissions 